\title{
The Role of Phosphate in the Secretion of Parathyroid Hormone in Man
}

\author{
Eric Reiss, Janet M. Canterbury, Margaret A. Bercovitz, and \\ EDWIN L. KAPLAN \\ From the Departments of Medicine and Surgery, Michael Reese Hospital and \\ Medical Center and the University of Chicago Pritzker School of Medicine, \\ Chicago, Illinois 60616
}

\begin{abstract}
A в S T R A C T In man, oral administration of $1 \mathrm{~g}$ of phosphorus resulted in a $60-125 \%$ increase in serum immunoassayable parathyroid hormone (PTH) concentration. Peak PTH levels were attained in $1 \mathrm{hr}$, and PTH returned to base line levels in $2 \mathrm{hr}$. This increase in PTH appeared to be initiated by a very small decrease of total and ionized calcium and was abolished by a calcium infusion. There was no correlation between serum phosphorus and PTH. The experiments show that oral phosphorus administration initiates a calcium-mediated control system for PTH secretion and that this system operates very sensitively in man.
\end{abstract}

\section{INTRODUCTION}

All available evidence indicates that the concentration of serum calcium regulates secretion of parathyroid hormone (PTH) (1-4). The best direct data are derived from studies in cows (3). Infusions of phosphate increase plasma PTH but only when the serum phosphorus concentration is increased sufficiently so that a reciprocal depression of serum calcium is achieved. Since large increases of serum phosphorus are required for serum calcium to decrease and for PTH to increase, these studies show that the phosphate-initiated, calcium-mediated control of PTH secretion in cows is insensitive.

Indirect evidence suggests that this control system operates more sensitively in the dog (5). In this species, very small increases of serum phosphorus result in brisk phosphaturia. This response appears to be mediated by very small decreases of serum calcium and depends on the presence of intact parathyroid function.

The present studies were designed to examine the effect of oral phosphate administration on PTH secretion in man.

Received for publication 18 June 1970.

\section{METHODS}

Five normal adult subjects, three women and two men, were studied in the postabsorptive state, starting at 9 a.m. They were permitted to drink water and black coffee. Venous

TABLE I

Effect of Oral Phosphate on Serum Calcium, Phosphorus, and PTH

\begin{tabular}{|c|c|c|c|c|}
\hline Subject & Time & Calcium & $\begin{array}{l}\text { Phos- } \\
\text { phorus }\end{array}$ & PTH \\
\hline & $\min$ & $m g / 100 m l$ & $\begin{array}{c}\mathrm{mg} / \\
100 \mathrm{ml}\end{array}$ & $\begin{array}{c}\mu l \text { stand- } \\
\text { ard } / \mathrm{ml}\end{array}$ \\
\hline \multirow[t]{9}{*}{ L. T., woman, age 27} & -15 & $9.15(4.32)$ & 3.2 & 60 \\
\hline & 15 & $9.15(4.28)$ & 3.2 & 60 \\
\hline & 30 & $8.85(4.25)$ & 4.0 & 65 \\
\hline & 45 & $9.05(4.18)$ & 4.0 & 90 \\
\hline & 60 & $8.95(4.07)$ & 4.0 & 130 \\
\hline & 75 & $9.05(4.18)$ & 4.4 & 120 \\
\hline & 90 & $8.95(4.14)$ & 4.5 & 70 \\
\hline & 105 & $8.95(4.14)$ & 4.5 & 65 \\
\hline & 120 & $9.05(4.21)$ & 4.2 & 55 \\
\hline \multirow[t]{12}{*}{ P. B., woman, age 23} & -15 & 9.18 & 3.4 & 30 \\
\hline & 10 & 8.94 & 3.4 & 35 \\
\hline & 20 & 9.04 & 3.6 & 35 \\
\hline & 30 & 8.98 & 3.6 & 30 \\
\hline & 40 & 8.95 & 4.0 & 45 \\
\hline & 50 & 9.18 & 3.9 & 60 \\
\hline & 65 & 8.70 & 3.8 & 75 \\
\hline & 80 & 8.20 & 3.8 & 70 \\
\hline & 95 & 8.24 & 4.0 & 60 \\
\hline & 110 & 8.24 & 4.0 & 65 \\
\hline & 125 & 8.94 & 3.8 & 40 \\
\hline & 140 & 9.66 & 4.0 & 35 \\
\hline \multirow[t]{9}{*}{ M. T., woman, age 23} & -15 & 10.0 & 3.6 & 55 \\
\hline & 15 & 9.96 & 3.7 & 45 \\
\hline & 30 & 9.73 & 3.7 & 50 \\
\hline & 45 & 9.58 & 3.5 & 60 \\
\hline & 60 & 9.39 & 3.6 & 70 \\
\hline & 75 & 9.55 & 4.0 & 80 \\
\hline & 90 & 9.40 & 4.0 & 60 \\
\hline & 105 & 9.69 & 4.1 & 60 \\
\hline & 120 & 9.44 & 3.9 & 50 \\
\hline
\end{tabular}

$1 \mathrm{~g}$ of oral phosphate was given at time zero. In subject $\mathrm{L}$. T., numbers in parenthesis represent ionized calcium. For normal ranges see Fig. 1. Italicized numbers indicate maximal changes from base line values. 
blood was drawn without stasis through an indwelling venous catheter kept patent between samplings with heparin. Before obtaining a test sample, $5 \mathrm{ml}$ of blood was withdrawn and discarded to assure the obtaining of blood not contaminated with heparin.

After a base line specimen of blood was obtained, $1 \mathrm{~g}$ of phosphorus was given by mouth as buffered sodium phosphate, $\mathrm{pH}$ 7.4. Venous blood was collected at 10-15-min intervals for $2 \mathrm{hr}$.

One subject was studied a second time under identical circumstances except for the infusion of $2 \mathrm{mg}$ of calcium per $\mathrm{kg}$ per $\mathrm{hr}$ in the form of calcium gluconate-glucoheptonate in the arm opposite to the sampling site.

Serum calcium was measured by atomic absorption spectrometry (Instrumentation Laboratory, Inc., Lexington, Mass.; Model 153); ionized calcium by an Orion flowthrough electrode system (two subjects). (Orion Research, Inc., Cambridge, Mass.) (6) ; and serum phosphorus by a modified Fiske-Subbarow AutoAnalyzer method. Serum PTH was measured by radioimmunoassay $(7,8)$.

\section{RESULTS}

The serum concentration of PTH in normal subjects by the method used is $10-60 \mu \mathrm{Eq} / \mathrm{ml}$, an arbitrary unit of measurement relating the potency of a test serum to that of a standard hyperparathyroid serum $(8,9)$. Base line values of PTH were normal in all subjects. Serum PTH remained constant for 30-50 min after administration of oral phosphate and then increased to $60-125 \%$ above base line, four of the five subjects showing a $100 \%$ or greater increase. From the peak levels attained in $60-75$ $\mathrm{min}$, PTH decreased to control values in $105-125 \mathrm{~min}$.

Oral phosphate administration was associated with a decrease of total calcium ranging from 0.3 to $1.1 \mathrm{mg} / 100$ $\mathrm{ml}$. In the two subjects in whom ionized calcium was also measured, total and ionized calcium changed proportionately (Fig. 1; Table I). Rising serum PTH was preceded or accompanied by a small decrease of serum calcium. Although the serum calcium was increasing toward normal at the end of the $2 \mathrm{hr}$ experiment in all subjects, it had not returned to base line values by that time. In the subject studied a second time combining oral phosphate with an intravenous calcium infusion, serum calcium increased and PTH decreased (Fig. 2).

Serum phosphorus increased in four subjects after oral phosphate, but the extent and timing of increase was highly variable. These changes were not well correlated with either serum calcium or PTH. Serum phosphorus remained elevated above base line at the termination of the experiments.

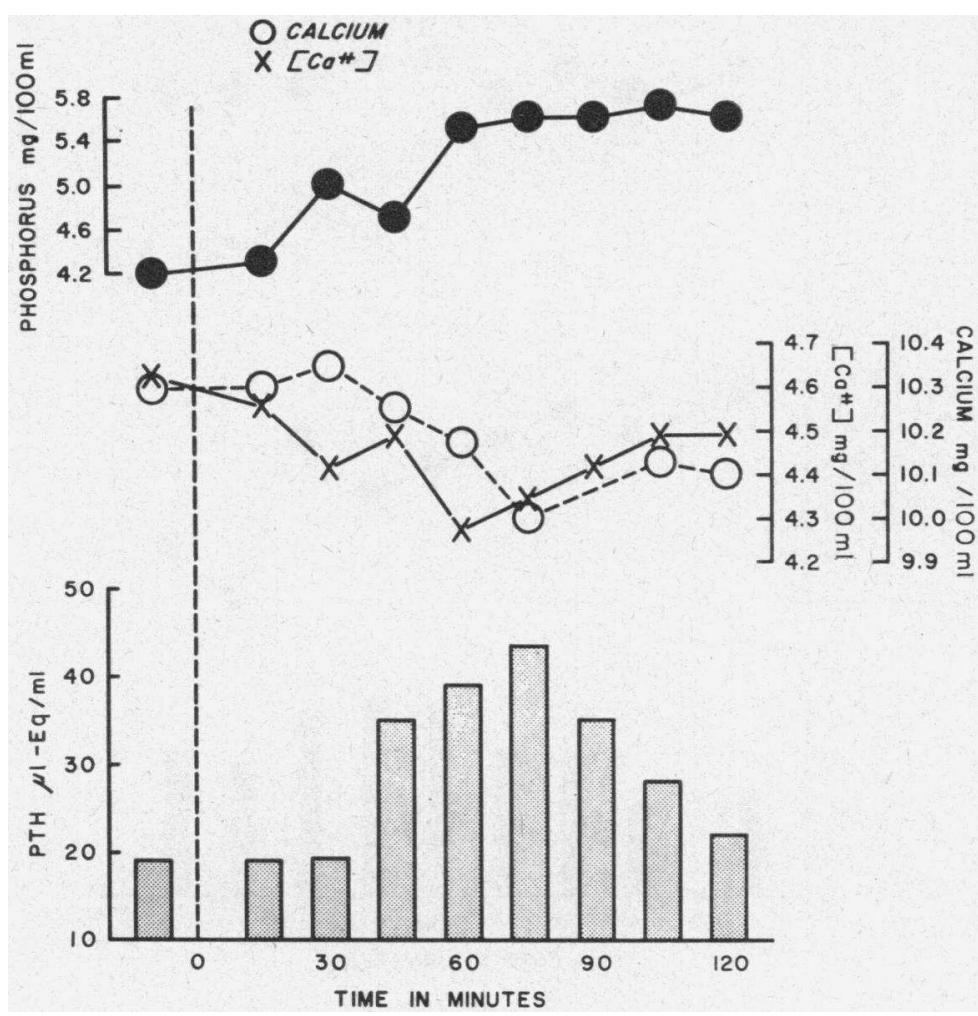

Figure 1 Effect of oral phosphate on serum PTH, total calcium, ionized calcium, and phosphorus in a normal man, age 29. Normal ranges: PTH, $10-60 \mu \mathrm{Eq} / \mathrm{ml}$; total calcium, $9.0-10.5 \mathrm{mg} / 100 \mathrm{ml}$; ionized calcium, $4.08-4.80 \mathrm{mg} / 100 \mathrm{ml}$; and phosphorus $3.0-4.5 \mathrm{mg} / 100 \mathrm{ml}$. 


\section{DISCUSSION}

The radioimmunoassay of PTH used in these studies is a modification of the procedure of Berson and Yalow (7, 9). Our assay (8) has the following two limitations: (a) the problem of immunologic heterogeneity of parathyroid secretions has not been defined with our antiserum (10), and (b) the apparent half-time of hormone disappearance from serum when secretion is suppressed by hypercalcemia is approximately $3 \mathrm{hr}$ (11). By contrast, the half-time in the cow is $18 \mathrm{~min}$, a value that is more consonant with the turnover of most polypeptide hormones (3). Despite these unresolved problems, the assay has yielded highly reproducible results and excellent clinicopathologic correlations $(11,12)$.

The present data confirm that phosphate per se does not influence PTH secretion in man, a conclusion well established in other species. This is evident from the failure of oral phosphate to increase serum PTH when hypocalcemia is prevented by a calcium infusion and from the lack of correlation between serum phosphorus and PTH.

The data show that oral phosphate administration is followed by a consistent and brisk rise of serum PTH. The initial rise of PTH is well correlated with a small decrease of ionized calcium and a proportionate decrease of total calcium, suggesting that a small decline of serum calcium serves as the stimulus for PTH secretion. The large increase of PTH in response to a very small decrease of serum calcium and the poor correlation between $\mathrm{PTH}$ and serum calcium in the later phases of each experiment may be examples of a derivative rather than proportional control mechanism, as Sherwood, Mayer, Romberg, Kronfeld, Aurbach, and Potts have suggested (3).

Although hypocalcemia initiates PTH secretion, it is clear that the system also operates to maintain phosphate homeostasis; increased PTH secretion results in phosphaturia and thus promotes disposition of an oral phosphate load. The sensitivity of the system in man provides

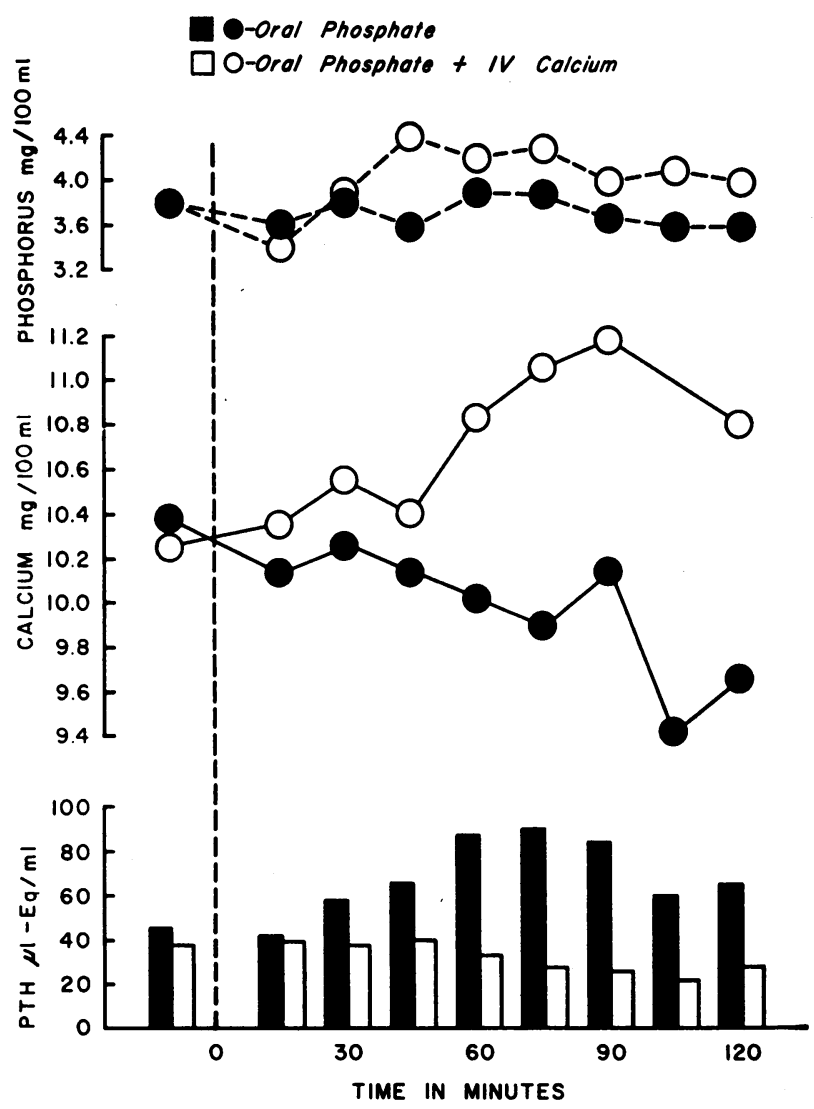

Figure 2 Two separate experiments on the effect of oral phosphate on serum PTH, total calcium, and phosphorus in a normal man, age 46 , with and without an intravenous infusion of calcium. Closed symbols: oral phosphate alone. Open symbols: oral phophate plus intravenous calcium. 
indirect support for the theory of Bricker, Slatopolsky, Reiss, and Avioli according to which early renal hyperparathyroidism results from minimal hypocalcemia that is induced by phosphate retention (13). By its phosphaturic action, increased secretion of $\mathrm{PTH}$ restores phosphate balance and abolishes hypocalcemia. Calcium and phosphorus homeostasis are thus maintained at the expense of some degree of hyperparathyroidism.

\section{ACKNOWLEDGMENTS}

This work was supported by Research Grants AM-08572 and AM-14498 from the National Institute of Arthritis and Metabolic Diseases.

\section{REFERENCES}

1. Patt, H. M., and A. B. Luckhardt. 1942. Relationship of a low blood calcium to parathyroid secretion. Endocrinology. $31: 384$.

2. Dale, D. C., S. I. Roth, and G. E. Garcia. 1965. Effect of calcium on parathyroid secretion. Endocrinology. 77: 725.

3. Sherwood, L. M., G. P. Mayer, C. F. Romberg, Jr., D. S. Kronfeld, G. D. Aurbach, and J. T. Potts, Jr. 1968. Regulation of parathyroid hormone secretion: proportional control by calcium, lack of effect of phosphate. Endocrinology. 83: 1043.

4. Potts, J. T., Jr., and L. J. Deftos. 1969. Parathyroid hormone, thyrocalcitonin, vitamin $\mathrm{D}$, bone and bone mineral metabolism. In Duncan's Diseases of Metabolism. P. K. Bondy, editor. W. B. Saunders Company, Philadelphia. 6th edition 2: 904.
5. Morrin, P. A. F., W. B. Gedney, and E. Reiss. 1962. Phosphate homeostasis: sensitivity of parathyroid-mediated response of renal excretion. J. Lab. Clin. Med. 59: 387.

6. Moore, E. W. 1970. Ionized calcium in normal serum, ultrafiltrates, and whole blood determined by ion-exchanged electrodes. J. Clin. Invest. 49: 318.

7. Berson, S. A., R. S. Yalow, G. D. Aurbach, and J. T. Potts, Jr. 1963. Immunoassay of bovine and human parathyroid hormone. Proc. Nat. Acad. Sci. U.S. A. 49: 613.

8. Reiss, E., and J. M. Canterbury. 1968. A radioimmunoassay for parathyroid hormone in man. Proc. Soc. Exp. Biol. Med. 128: 501 .

9. Berson, S. A., and R. S. Yalow. 1966. Parathyroid hormone in plasma in adenomatous hyperparathyroidism, uremia and bronchogenic carcinoma. Science (Washington). 154: 907.

10. Berson, S. A., and R. S. Yalow. 1968. Immunochemical heterogeneity of parathyroid hormone in plasma. J. Clin. Endocrinol. Metab. 28: 1037.

11. Reiss, E., J. M. Canterbury, and R. H. Egdahl. 1968. Experience with a radioimmunoassay of parathyroid hormone in human sera. Trans. Ass. Amer. Physicians Philadelphia. 81: 104.

12. Reiss, E., and J. M. Canterbury. 1969. Application of radioimmunoassay to differentiation of adenoma and hyperplasia and to preoperative localization of hyperfunctioning parathyroid glands. New Engl. J. Med. 280: 1381.

13. Bricker, N. S., E. Slatopolsky, E. Reiss, and L. V. Avioli. 1969. Calcium, phosphorus, and bone in renal disease and transplantation. Arch. Intern. Med. 123: 543. 